つぎに，溶出溶媒を石油エーテル：ベンゼン $(3: 2)$ とし，第 2 の流出物として $\mathrm{mp} 158^{\circ} \sim 160^{\circ} \mathrm{C}$ の結晶(エタノールタら再結晶) を得た。 4.1 で得た $\mathbb{V}$ との混融で trans- $\alpha, \alpha^{\prime}$-シシシアンスチルベ ンであることを確認した。

さらに，溶出溶媒をベンゼンに变え，第 3 の流出物として mp $218^{\circ} \mathrm{G}$ の結晶(ベンゼンから再結晶)を得た。Reimer ${ }^{13}$ )の方法で

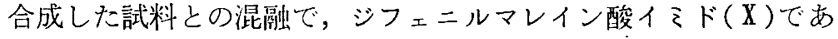
ることを確認した。

分析值 C $77.04 \%, \mathrm{H} 4.54 \%, \mathrm{~N} 5.92 \%, \mathrm{O} 12.81 \%$ 分子量 264

$\mathrm{C}_{16} \mathrm{H}_{11} \mathrm{O}_{2} \mathrm{~N}$ としての

計算值 C $77.09 \% ， \mathrm{H} 4.55 \% ， \mathrm{~N} 5.62 \% ， \mathrm{O} 12.84 \%$ 分子量 249

クロマトの最後の流出物はアメようの物質で，エーテルに溶解 し，石油エーテルを加えると粉末状のポリマーが析出した。これ をポリマー(Q)とした。 $80^{\circ} \mathrm{C} ， 4$ 時間の反応で得た試料を例にと ると，

分析值 C 78.89\%, H 4.06\%, N 8.53\%, O 7.52\% 分子量 4585

ポリマー(Q)を得た日液を登発するとアメようのポリマーが残 った。このものをポリマー $(\mathrm{P})$ とした。このポリマーの赤外吸収 スペクトルはポリマー $(\mathrm{N})$ のスペクトルに一致する。

これら生成物の収率を 2.2 の表 5 に示した。

4.3 trans-a, $\boldsymbol{a}^{\prime}$-ジシアンスチルベン $(\mathrm{IV})$ と過酸化ニッヶル

\section{との反応}

IV の $0.15 \mathrm{~g}$ をベンゼン $5 \mathrm{ml}$ に溶かし，過酸化ニッケル $(f=$ 0.0387)の $0.41 \mathrm{~g}$ を加え，かきまぜながら 4 時間加熱還流した。

反応液を口過し，ケーキをベンゼンで洗浄した。口洗液を合わ せて浱縮し， $0.4 \mathrm{~g}$ の淡黄白色の結晶を得た。エタノールから再 結晶すると白色の $\mathrm{mp} 158^{\circ} \sim 160^{\circ} \mathrm{C}$ の結晶となった。混融で原 料(IV)であることを確かめた。回収率 97\%。

4.4 cis $-\boldsymbol{\alpha}, \boldsymbol{\alpha}^{\prime}$-ジシアンス チルベン $(\mathbf{V})$ と過酸化ニッケルとの 反応

$\mathrm{V}$ の $0.15 \mathrm{~g}$ をベンゼン $5 \mathrm{ml}$ に溶かし, 過酸化ニッケル $(f=$ 0.0389)の $0.41 \mathrm{~g}$ を加え， 4 時間かきまぜながら加熱還流した。

反応液をロ過し，ケーキをベンゼンで洗浄した。洗液を合わ せて蒸発乾固した。残留物をエーテルから再結晶し，0.13 g の結 晶を得た。混融で原料 $(V)$ であることを確認した。回収率 $87 \%$ 。

母液を涉縮し，その残留物をシリカゲル薄層クロマトで処理し た。展開溶媒としてクロロホルムを使用し， $R_{f} 0.15$ の部分から

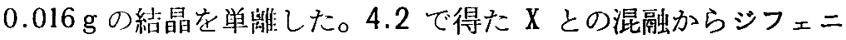
ルマレイン酸イミドであることを確認した。収率 $10 \%$ 。

終りに，本研究において種々御指導をしていただいた大阪大学 理学部村橋俊介教授に媣甚の謝意を表わすとともに，終始御鞭㼀 を賜わった当社研究所長武田健一博士, 研究員沢 芳郎博士, 中 川国夫博士に厚く感謝致します。また実験に協力された長衛次郎 氏に感謝致します。

\title{
5-オキシー，7-オキシーおよび 5,7-ジオキシフラボンの白金触媒による接触還元*1
}

(昭和 42 年 2 月 21 日受理)

鈴 木 盛 $夫 * 2$ ·水 野 英 雄*2 高 井 将 博*3

フラボン骨格のどの原子団が選択的に水素化されるかを検討する目的で，5-オキシー，5,7-ジオキシー，7-オキシー，7-メトキシー および 7ーフセトキシフラボンの接触還元を行なった。エタノール中で白金触媒を使用して還元を行ない水素吸収のおをくなった 点で反応を中止すると，5-オキシフラボンからは 2-シクロへキシル-5-オキシクロモン $\left(\mathrm{mp} 102.5^{\circ} \mathrm{C}\right)$ が $74 \%$ の収率で得られた。

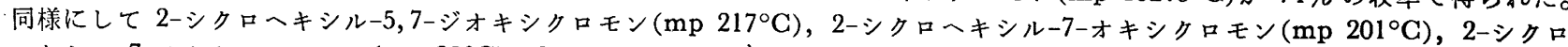

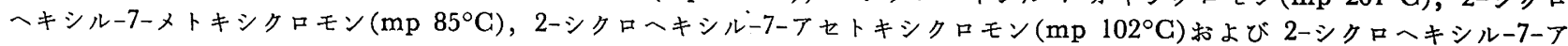
セトキシクロマノン $\left(\mathrm{mp} 69^{\circ} \mathrm{C}\right)$ が相当するフラボン誘導体から好収率で得られ, 上述のフラボン誘導体の場合には 2 位のフェニル 基が選択的に水絜化されることを明らかにした。

\section{1 緒言}

白金触媒を用いてフラボンおよびその誘導体*4 の接触還元を行 なった研究は 3 例堑告されている。三井ら1 は酢酸中で室温常圧

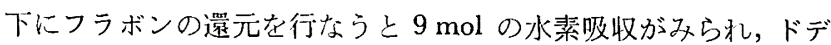
カヒドロフラバンが得られたと報告している。Freudenberg ら2)

*1この報文を“フラボン誘導体の選択的接触還元に関する 砟究(第 1 報)”とする.

*2 Morio Suzuki, Hideo Mizuno 静阙大学工学部工業化 学科, 浜松市城北

*3 Masahiro TAKAI 現在東亜合成化学工業株式会社名古 屋工業所，名古屋市港区昭和町

*4 フラボノール(3-オキシフラボン)誘導体は除く.

1) 三井生喜雄，幾石敬夫，日化，71，203(1950)。

2) K. Freudenberg, A. Kamüller, Ann., 451, 209(1927).
ばテトラメチルルテオリンを酢酸中で還元すると水素吸収は 3 molでとまりテトラメチルデソキシカテキンが得られたと報告し ており，この場合には $\gamma$ ーピロン環の炭素間二重結合とカルボニ ル基とが選択的に水秦化されている。また, Geissman らろはエ タノール中で室温加压下 $(2 \sim 2.7 \mathrm{~atm})$ にルテオリンの還元を行な うとエリオジクチオールが得られたと報告しており，この場合に は $\gamma$ ーピロン環の炭素間二重結合だけが水素化されている。

著者らは，フラボン誘導体が白金触媒の存在下にエタノール中 で還元されるさいに $\gamma$-ピロン環が選択的に 水素化されるかどう かという問題に興味を持ち, 5-オキシフラボン(I ), 5, 7-ジオキシ フラボン(クリシン)(II)，7-オキシフラボン(II)，7-メトキシフ

3) T. A. Geissman, R. O. Clinton, J. Am. Chem. Soc., $68,697(1946)$. 
ラボン (IV) および 7-アセトキシフラボン (V)について按触還元 を試みたが, Freudenberg ら²)や Geissman ら゙の場合とまった く異なる結果が得ら富りたので報告する。

\section{2. 結果}

\section{1 水素吸収曲線の変曲点}

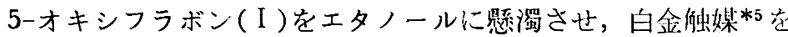
用いて室温常压下に接触還元を行なうと, 約 $2 \mathrm{~mol}$ の水素吸収の みられる点でI はエタノールに完全に溶け， $3 \mathrm{~mol}$ の水素吸収の ある点から吸収速度は急激におそくなる。本研笢では，三井ら1 の研究のようにフラボンを徹底的に水素化するのが目的ではな く，ドデカヒドロフラバンにいたる途中でフラボン骨格のどこの 原子団に選択的に水素化が起るかを検討することに目的があるの で，この水素吸収曲線の変曲点をやや過ぎたところで還元を中止 して生成物を取りだすこととした。表 1 に I〜Vについての水絜 吸収曲線の変曲点と生成物を取りだすために反応を中止したとき の水素吸収量とを記した。

Iおよび IIについては水素吸収量が $3 \mathrm{~mol}$ 近辺で吸収速度が いちじるしくおそくなるのが認められたが，IIIVについては吸 収速度の変化はそれほど明確でない。水素吸収曲線は触媒量によ

裴 1 水絜吸収曲線の変曲点

(試料 $1 / 200 \mathrm{~mol}, \mathrm{EtOH} 150 \mathrm{ml}$, 室温常压)

\begin{tabular}{|c|c|c|c|}
\hline $\begin{array}{l}\text { 試 } \\
\text { (フラボン) }\end{array}$ & $\left.\begin{array}{c}\text { 触媒量 } \\
\mathrm{g} \\
\left(\mathrm{PtO}_{2}\right.\end{array}\right)$ & 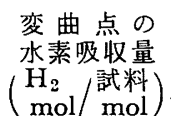 & 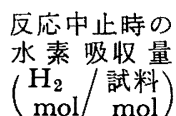 \\
\hline シ-a) & 0.10 & 3.0 & 3.4 \\
\hline 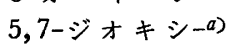 & 0.10 & 2.8 & 3.3 \\
\hline $7-\pi \neq \dot{y}^{-b}$ & 0.24 & 2.9 & 3.2 \\
\hline $7-x \quad 卜 \neq シ-b)$ & 0.30 & 5.5 & $3.5,5.5$ \\
\hline 7ーアセトキシーb) & 0.10 & 2.9 & $3.2,3.7$ \\
\hline
\end{tabular}

注 $\quad a ）$ 試料をエタノールに懸濁した状態で反応を開始した。 約 $2 \mathrm{~mol}$ の水素を吸収すると溶液となる。

$b$ ）試料は溶液となっている。<smiles>[R]c1cc(O)c2c(c1)Oc1ccccc1C(=O)C2</smiles>

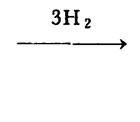

(I ) $\mathrm{R}=\mathrm{H}$

(II) $\mathrm{R}=\mathrm{OH}$<smiles>[R20]Oc1ccc2c(c1)Oc1ccccc1CC2=O</smiles>

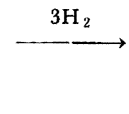

(III) $\mathrm{R}=\mathrm{H}$

$\begin{array}{ll}\text { (IV) } & \mathrm{R}=\mathrm{CH}_{3} \\ \text { (V) } & \mathrm{R}=\mathrm{CH}_{3} \mathrm{CO}\end{array}$
り変化与るので II V については触媒量を加減して吸収曲線に変 曲点が現われるような条件を求めた。したがって表1にみられる ように，試料によって使用した触媒量はまちまちである。

\section{2 還元生成物}

表 1 に記してある水素吸収のあった点で反応を中止して生成物 を取りだし，その棈造を検討した。

Iからは mp $102^{\circ} \sim 102.5^{\circ} \mathrm{C}$ の結晶(Ia)が $74 \%$ の収率で得ら れた。I a は $\mathrm{C}_{15} \mathrm{H}_{16} \mathrm{O}_{3}$ に相当する組成を有するので I $\left(\mathrm{C}_{15} \mathrm{H}_{10} \mathrm{O}_{3}\right)$ に $3 \mathrm{~mol}$ の水素が付加して生じた物質であり，赤外吸収スペク トルをみると共役カルボニル基の存在 $\left(1652 \mathrm{~cm}^{-1}\right)$ がわかる。し たがって，この物質はI の 2 位のフェニル基が水秦添加を受けて 生じた 2-シクロヘキシル-5-オキシクロモン(Ia)か，I のクロモ ン瑾を形成しているベンゼン核に水素が付加して生じた Ib(図 1) のどちらかであるが，塩化鉄(III)によって紫色に呈色するのでフ ェノール性水酸基の存在を示し，Ia の構造を有することが確か められた。

II からは mp $216^{\circ} \sim 217^{\circ} \mathrm{C}$ の結晶(IIa)が $74 \%$ の収率で得ら れ，Ila j゙ 2-シクロヘキシル-5,7-ジオキシクロモンであること が，Ia と同様に，元素分析，赤外吸収スペクトルおよび呈色反 応から確かめられた。

表 2 に還元生成物の収率と性質とを，表 3 亿炭水秦分析の絬果 を，表 4 に僈元生成物および関連化合物の $\mathrm{C}=\mathrm{O}$ 伸縮による赫外 吸収の位置を記した。

\section{表 3 還元生成物の元垁分析}

\begin{tabular}{|c|c|c|c|c|c|}
\hline \multirow{2}{*}{$\begin{array}{l}\text { 還 元 } \\
\text { 生成物 }\end{array}$} & \multirow{2}{*}{ 分子式 } & \multicolumn{2}{|c|}{$\mathrm{G}(\%)$} & \multicolumn{2}{|c|}{$\mathrm{H}(\%)$} \\
\hline & & 計算值 & 分析值 & 計算值 & 分析値 \\
\hline I a & $\mathrm{C}_{15} \mathrm{H}_{16} \mathrm{O}_{3}$ & 73.75 & 73.49 & 6.60 & 6.86 \\
\hline $\mathbb{I I a}$ & $\mathrm{C}_{15} \mathrm{H}_{16} \mathrm{O}_{4}$ & 69.21 & 69.24 & 6.20 & 6.29 \\
\hline $\mathbb{I I} \mathbf{a}$ & $\mathrm{C}_{15} \mathrm{H}_{16} \mathrm{O}_{3}$ & 73.75 & 74.10 & 6.60 & 6.65 \\
\hline $\mathrm{IVa}$ & $\mathrm{C}_{16} \mathrm{H}_{18} \mathrm{O}_{3}$ & 74.39 & 74.21 & 7.02 & 6.97 \\
\hline $\mathrm{Va}$ & $\mathrm{C}_{17} \mathrm{H}_{18} \mathrm{O}_{4}$ & 71.31 & 70.91 & 6.34 & 6.33 \\
\hline $\mathrm{Vb}$ & $\mathrm{C}_{17} \mathrm{H}_{20} \mathrm{O}_{4}$ & 70.81 & 70.88 & 6.99 & 6.63 \\
\hline
\end{tabular}<smiles></smiles>

(Ia) $\mathrm{R}=\mathrm{H}$

(IIa) $\mathrm{R}=\mathrm{OH}$<smiles>[R20]c1ccc2c(c1)OC1CCCCC1CC2=O</smiles>

$\begin{array}{ll}\text { (IIa) } & \mathrm{R}=\mathrm{H} \\ \text { (IV) } & \mathrm{R}=\mathrm{CH}_{3} \\ \text { (Va) } & \mathrm{R}=\mathrm{CH}_{3} \mathrm{CO}\end{array}$<smiles>CC1C(O)CCCC1OC1=CC(=O)CC=C1</smiles>

( I b)<smiles>COc1ccc2c(c1)OC(c1ccccc1)CC2=O</smiles>

( $\mathrm{Vb})$
図1 反応式

装 2 還元生成物 の 收淘と性質

物 質 名 收率 $(\%)$ 瀜点 $\left({ }^{\circ} \mathrm{C}\right) \quad$ 形 $\quad$ 状 $\quad \mathrm{FeCl}_{3} \quad 2 \mathrm{~N} \mathrm{NaOH}$ 2-シクロへキシル-5-オキシクロモン (Ia) 2-シクロへキシル-5,7-ジオキシクロモン (IIa) 2-シクロへキシルー7-オキシクロモン (IIa) 2-シクロへキシル-7-メトキシクロモン (NVa) 2-シクロへキシルー7-フセトキシクロモン $(\mathrm{Va})$ 2-シクロへキシルー7-フセトキシクロマノン (Vb)

$\begin{array}{lc}74 & 102 \sim 102.5 \\ 74 & 216 \sim 217 \\ 54 & 200 \sim 201 \\ 60 & 84.2 \sim 85 \\ 50 & 101.5 \sim 102 \\ 38 & 67.5 \sim 69\end{array}$
淡 黄色，柱状絬晶 白色, 針状絬晶 白色, 針状結晶 白色，針状結晶 白色，プリズム状結晶 白色, 針状結晶

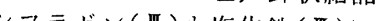

$\begin{array}{cc}\mathrm{FeCl}_{3} & 2 \mathrm{~N} \mathrm{NaOH} \\ \text { 紫色 } & \text { 不溶 } \\ \text { 赤紫 } \\ \text { 呈色せずb) } & \text { 溶 } \\ \text { 呈色せず } & \text { 溶 } \\ \text { 呈色せず } & \text { 不溶 } \\ \text { 呈せ色せず } & \text { 不溶 }\end{array}$


表 4 赤外吸収による $\mathrm{C}=\mathrm{O}$ 伸縮 $\left(\mathrm{cm}^{-1}\right)(\mathrm{KBr}$ 錠郕)

\begin{tabular}{|c|c|c|c|}
\hline I & 1654 & IV & 1650 \\
\hline Ia & 1652 & $\mathrm{IVa}$ & 1648 \\
\hline II & 1653 & V & 1635,1764 \\
\hline II a & 1660 & $\mathrm{Va}$ & 1644,1763 \\
\hline II & 1630 & $\mathrm{Vb}$ & 1690,1765 \\
\hline II & 1631 & $\begin{array}{l}\text { 7ーアセトキシー } \\
\text { フラバノン }\end{array}$ & 1693,1761 \\
\hline
\end{tabular}

IIIから mp $200^{\circ} \sim 201^{\circ} \mathrm{C}$ の結晶(IIa)が $54 \%$ の収䔬で得ら れ，III が 2-シクロヘキシル-7-オキシクロモンであることが Ia および Ia と同様にして確かめられた。

$\mathbb{N}$ は $5.5 \mathrm{~mol}$ の水素吸収のあるところに吸収曲線の変曲点が 現われるが，この点で反応を中止すると生成物は油状となり結晶 を得ることができない。そこで， $3.5 \mathrm{~mol}$ の水素吸収のあった点 (この辺に吸収速度の 変化はみられない)で反応を中止すると， $\mathrm{mp} 84.2^{\circ} \sim 85^{\circ} \mathrm{C}$ の結晶(Na)が $60 \%$ 収詧で得られた。 $\mathrm{Na}$ は $\mathbb{V}$ に $3 \mathrm{~mol}$ の水榇が付加した分子式を有し，共役カルボニル基を 有する。この物質は IIIaメチル化によっても得られるので2-シ

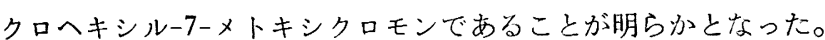

$\mathrm{V}$ が $3.2 \mathrm{~mol}$ の水素を收収した点で反応を中止与ると， mp $101.5^{\circ} \sim 102^{\circ} \mathrm{C}$ の結晶(Va)が 50\%の収率で得られた。Va は II a のアセチル化によっても得られるので 2-シクロヘキシルー7-アセ トキシクロモンである。V が $3.7 \mathrm{~mol}$ の水素を吸収した点で反 応を中止すると, $\mathrm{mp} 67.5^{\circ} \sim 69^{\circ} \mathrm{C}$ の結晶(Vb)が $38 \%$ の収率で 得られた。 Vb は $\mathrm{C}_{17} \mathrm{H}_{20} \mathrm{O}_{4}$ の組成を有し, $\mathrm{V}\left(\mathrm{C}_{17} \mathrm{H}_{12} \mathrm{O}_{4}\right)$ に $4 \mathrm{~mol}$ の水素が付加して生じた物質である。 $\mathrm{Vb}$ の赤外吸収スペクトル によるカルボニル基の位置はフラボン型でなくフラバノン型であ る。また，紫外吸収スペクトル(図 2)が 7-アセトキシラフバノ ンとほとえど一致していることから Vb は 2-シクロヘキシル-7アセトキシクロマノンであると考えられる。

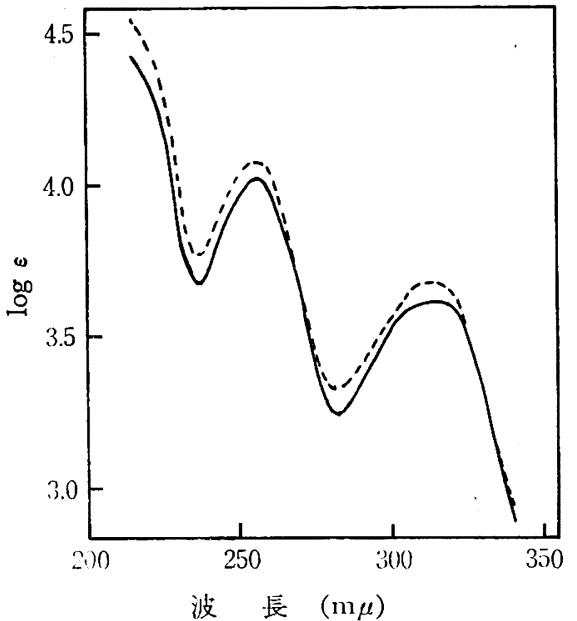

一：7ーナセトキシー2-シクロヘキシルクロマノン

$\left(\lambda_{\max } 257,315 \mathrm{~m} \mu\right)$

----: 7-アセトキシフラハシノソ

$\left(\lambda_{\max } 255,315 \mathrm{~m} \mu\right)$

図 2 Vbの紫外吸收スペクトル

上に述ベたように，I〜V のフラボン誘導体はエタノール中で 白金虽媒を使用して接触還元を行なうと，最初に 2 位のフェニル 基に水絜付加が起ると考えられる。この傾向は，還元生成物の収
率の高いことから I および II にとくにいちじるしいと考えられ る。III およびその誘導体(IV および V)の還元生成物の収率はやや 低いので， $\gamma$-ピロン環に水絜化の起ることも考えられるが，その 程度は少ないものと思われる。

3 考察

著者らの実駗結果は Geissman ら ${ }^{3)}$ の結果と異なっているが， その原因としてつぎの二つが考えられる。一つは，フラボン誘導 '体の構造の相違である。ルテオリンは 3', 4', 5, 7-テトラオキシフ ラボンであるが，著者らが還元を行なった I〜V はいずれす 2 位 のフェニル基に水酸基を有していない。第 2 には，著者らの使用 した触媒と Geissman らの使用した触媒(両方とも Adams の酸 化白金であるが)との間に微妙な差異のあることが考えられる。 三井ら4)は触媒が微量の添加物の影響を受けてその触媒作用にい ちじるしい変化の起る例を多数報告している。これらの問題に関 しては以後に報告する予定である。

\section{4 実験}

\section{1 フラボン誘導体の合成}

4.1 .1 5-オキシフラボン (I)：Looker ら5)の方法によって合成 した。 $\mathrm{mp} 154^{\circ} \sim 154.5^{\circ} \mathrm{C}_{0}$

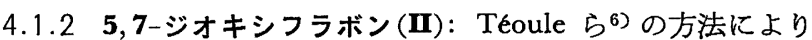
合成した。 $\mathrm{mp} 273^{\circ} \sim 275^{\circ} \mathrm{C}$ 。

4.1 .3 7-オキシフラボン(III)，7-メトキシフラボン(IV)およ び 7-アセトキシフラボン(V): Baker7)の方法にしたがい合成し た。 III $\mathrm{mp} 239^{\circ} \sim 240^{\circ} \mathrm{G}$, IV $\mathrm{mp} 109^{\circ} \sim 110^{\circ} \mathrm{C}, \mathrm{V} \mathrm{mp} 128^{\circ} \sim 129$ ${ }^{\circ} \mathrm{C}_{0}$

\section{2 接触僄元}

4.2.1 Adams の酸化白金: 小宗化学薬品製の試薬特級塩化白 金酸から製した。

4.2 .2 装置: ふりりぜ式常圧接触遠元装置を使用し 室温で反 応を行なった。

\section{3 還元生成物}

表 1 に記してある水素吸収のあった点で反応を中止し，触媒を 口別し，溶媒を留去した。以下には，残留物の状態，結晶化の条 件および再結晶溶媒について記した。生成物の性質および収率に ついては表 2 に, 元素分析の結果は表 3 に記してある。

4.3 .12 2-シクロヘキシル-5-オキシクロモン (Ia): 黄色アメ状 物。水室に一夜放置すると固化。メタノールから再結晶。

4.3 .2 2-シクロヘキシル-5,7-ジオキシクロモン (IIa): 白色固 体。エタノールから再結晶。

4.3.3 2-シクロヘキシル-7-オキシクロモン (IIa): 裪色アメ 状物。メタノールを加え氷室に一夜放置すると結晶化。口別して メタノールから再結晶。

4.3 .4 2-シクロヘキシル-7-メトキシクロモン $(\mathbf{I V a})$ : 白色固 体。石油エーテルから再結晶。

4.3 .5 2-シクロヘキシル-7-アセトキシクロモン $(\mathbf{V a})$ : 黄色ア

4) 三井生喜雄, 酒井孝真, 金子忠次, 日化, 86, 1328(1965).

5) J. H. Looker, J. R. Edman, J. I. Dappen, J. Heterocyclic Chem., 1, 141(1964).

6) R. Tèoule, G. Grenier, H. Pacheco, J. Chopin, Bull. Soc. Chim. France, 3, 546(1961).

7) W. Baker, J. Chem. Soc., 1933, 1381. 
メ状物*6。無水酢酸 $5 \mathrm{~m} l$ ，涠水酢酸ナトリウム $0.5 \mathrm{~g}$ とともに 湯浴上で 2 㭙間加熱し氷水に注ぐ。析出する油状物をエーテルで 抽出し, 酸性炭酸ナトリウム水, 水で洗い, 乾燥後溶媒を留去す る。残留する油状物に石油エーテルを加え氷室に 5 日間放置する と結晶化。口別後石油エーテルから再絬晶。

4.3.6 2-シクロヘキシル-7-アセトキシクロマノン(Vb): 淡黄 色アメ状物。石油エーテル $5 \mathrm{ml}$ で温時 5 回抽出する。抽出液を 合わせて室温に放置して析出する油状物を除き，氷室に一夜放置 すると結晶が析出する。別し石油エーテルから再結唱。

\subsection{Ia のメチル化およびアセチル化}

$0.2 \mathrm{~g}$ の III, $0.13 \mathrm{~g}$ の硫酸ジメチルおよび $0.2 \mathrm{~g}$ の無水炭酸

*6 酢酸臭が認められた。加水分解を受けていると考えられ る.
カリウム荙アセトン $2 \mathrm{ml}$ 中で 2 特間加熱還流して水水へ注ぐと 絬晶が得られる。石油ベンジンから再絬晶して $\mathrm{mp} 84^{\circ} \sim 85^{\circ} \mathrm{C}$ の白色針状絬晶が $0.15 \mathrm{~g}(71 \%)$ 得られた。混融試䓉および赤外 吸収スペクトルから $\mathrm{Va}$ と同定した。

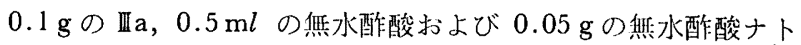
リウムを湯浴上で 2 時間加熱して氷水へ注ぐ。冷藏庫に一夜放置 与ると絬晶化与る。石油エーテルから再結晶して mp 100.5〜 $101.5^{\circ} \mathrm{C}$ の白色プリズム状絬晶 $0.07 \mathrm{~g}(60 \%)$ が得られた。混融 試験および赤外吸収スペクトルから Va と同定した。

本研究に御教示を賜わった東北大学工学部応用理学科三井生喜 雄教授に媣く感謝いたします。また，実騟に協力下さった静岡大 学工業短大学生中山 蔀君に謝意を表します。

（1966 作 10 月，日本化学会東海支部浜松地方大会発表）

\section{末端シクロヘキシル置換高級脂肪酸の合成 ${ }^{* 1, * 2}$ 直鎖部分に $\mathrm{C}_{20} \sim \mathrm{C}_{34}$ を有する偶数脂肪酸}

(昭和 42 年 2 月 24 日受理)

後 藤 良造·石 沢 昭 雄·山 村 正 美*3

長鎖状化合物における炭素鎖長，および鎖末端構造とその物理的性質との相関関係について榆討を行なう目的で，鎖末端位置を シクローキシル基で置換した化合物をとりあげ，まず， $\omega$-シクロへキシル脂肪酸，〈 $\langle\overrightarrow{\mathrm{H}}\rangle-\left(\mathrm{CH}_{2}\right)_{n} \cdot \mathrm{CO}_{2} \mathrm{H}(n=5,9,11,19,21,23$, $25,27,29,31,33)$ の合成を行なった。低級脂肪酸 $(n=5,9,11)$ は相当するフェニル脂肪酸の接触水素化で得た。高級脂肪酸 $(n=$ 19〜33)はすべて現在までに報告されていない新化合物であり，チオフェンを鎖延長郕とする方法によって合成した。これら脂肪

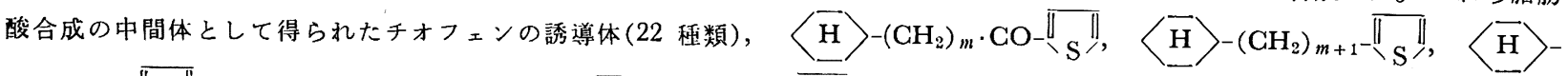

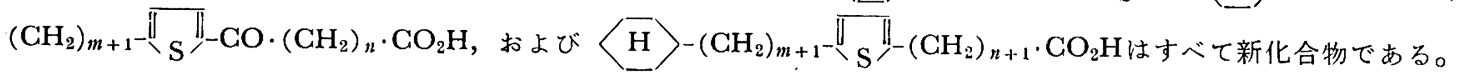

\section{1 緒言}

長鎖状化合物の合成およびその物性に関する研究は，Müller1) の行なった $n$-パラフィンに関する研究以来数多くなされ，その 研究対象物質はパラフィン2)，脂肪酸3，およびこれから得られる

*1この報交を“長鎖状化合物の合成と物性(第 7 報)”とす る.

*2 1959 年以降の長鎖状化合物に関する以下の報交はすべ て“長鎖状化合物の合成と物性”の表題下にまとめられ ることになった. A. Watanabe, Bull. Chem. Soc. Japan $32 ， 1295$ (1959) (第 1 報)；33，531(1960)(第 2 報)；34， 398(1961)(第 3 報)；34，1728(1961)(第 4 報)；36，336 (1963) (第 5 報); 後藤良造, 渡辺明, 北条 剛, 湔坂 祐夫, 日化, 87, 1220(1966)(第6 報).

*3 Ryozo Goto, Akio Ishizawa, Masami Yamamura 京 都大学理学部化学教室, 京都市左京区北白川追分町

1) A. Müller, Proc. Roy. Soc., A 127, 317(1929); 127, 417(1930); 138, 514(1932); 154, 624(1936).

2) a) A. R. Ubbelohde, Trans. Faraday Soc., 34, 282 (1938).

b) E. R. Andrew, J. Chem. Phys., 18, 607(1950).

3) a) F. Francis, S. H. Piper, T. Malkin, Proc. Roy. Soc., A 128, 214(1930).

b) F. Francis, F. Collins, S. H. Piper, ibid., A 158, 691 (1937).

c) T. D. Meyer, E. E. Reid, J. Am. Chem. Soc., 55, 1547(1933). エステル3b)3c)4), アルコール3b)3c)5), 八ロゲン化物3b3c)6), ア之 ンクなどにわたっている。しかし，炭素鎖の中間部あるいは直鎖 状脂肪酸や直鎖状アルコールなどのほか末端部に置換基をもつ長 鎖状化合物に関する研究は8 ${ }^{8}$ 少なく，ほとんど置換基をもたない 直鎖状化合物である。これは鎖長との関連において物性を検討与 ることが主たる目的であったことによるものと考えられる。

4) a) A. M. King, W. E. Garner, J. Chem. Soc., 1934, 1453.

b) R. W. Crowe, C. P. Smyth, J. Am. Chem. Soc., 73, 5401 (1951).

5) a) D. A. Wilson, E. Ott, J. Chem. Phys., 2, 231 (1934). b) H. Ott, Z. Physik. Chem., 193, 218(1944).

6) J. D. Hoffman, C. P. Smyth, J. Am. Chem. Soc., 72, 17I (1950).

7) a ) J. D. Hoffman, C. P. Smyth, ibid., 71, 3591 (1949).

b) 前報 (第 6 報), 後藤良造, 渡辺明, 北条 剛, 蓓坂 祐夫，日化，87，1220(1966)[この報文は第1 報とな っているが，ここで第6 報に訂正する].

8) L. A. Mikeska, C. A. Cohen, J. Org. Chem., 6, 784 (1941); A. W. Schmidt, A. Grosser, Ber., 73, 930 (1940); 75, 826(1942); R. W. Schiessler et al., Proc. Am. Petr. Inst., 23[ II ], 15(1942); 24[ II ], 49(1943); 26[ II ], 254(1946). 